\title{
Management of congenital heart disease
}

The past couple of decades have been a very exciting time for providers taking care of patients with congenital heart disease. We have made tremendous progress in almost all aspects and facets, ranging from early detection, better understanding of the basis of such defects, single ventricle palliation, cardiopulmonary bypass and heart transplantation. This has led to better survival and such survivors reaching adulthood, giving rise to a new and exploding field of adult congenital heart disease!

This series on the management of congenital heart disease aims to bring to the readers the tremendous advances that have been made in the field. The articles in this series have been contributed by the leaders in this field. The goal is to provide a very contemporary and practical update to various difficult problems and difficult to treat lesions in the field. Cardiopulmonary bypass, often taken for granted in the modern era, can be challenging to understand for the trainee. In comparison to the airline industry, a detailed and elaborate discussion of the whole process has been presented. A select group of difficult lesions have then been exhaustively discussed. The key to successful single ventricle palliation and the current challenges faced with the Fontan population are highlighted, leading to the current tremendous burden of adult congenital heart disease that all countries will face.

The edition ends with an exciting article on 3D printing and how this is changing the learning and training paradigm of congenital heart disease.

\section{Acknowledgments}

Funding: None.

\section{Footnote}

Provenance and Peer Review: This article was commissioned by the editorial office, Fournal of Thoracic Disease for the series "Management of Congenital Heart Disease". The article did not undergo external peer review.

Conflicts of Interest: The series "Management of Congenital Heart Disease" was commissioned by the editorial office without any funding or sponsorship. RAM serves as the unpaid editorial board member of fournal of Thoracic Disease from Apr 2019 to Mar 2021 and served as the unpaid Guest Editor of the series.

Ethical Statement: The author is accountable for all aspects of the work in ensuring that questions related to the accuracy or integrity of any part of the work are appropriately investigated and resolved.

Open Access Statement: This is an Open Access article distributed in accordance with the Creative Commons AttributionNonCommercial-NoDerivs 4.0 International License (CC BY-NC-ND 4.0), which permits the non-commercial replication and distribution of the article with the strict proviso that no changes or edits are made and the original work is properly cited (including links to both the formal publication through the relevant DOI and the license). See: https://creativecommons.org/ licenses/by-nc-nd/4.0/. 


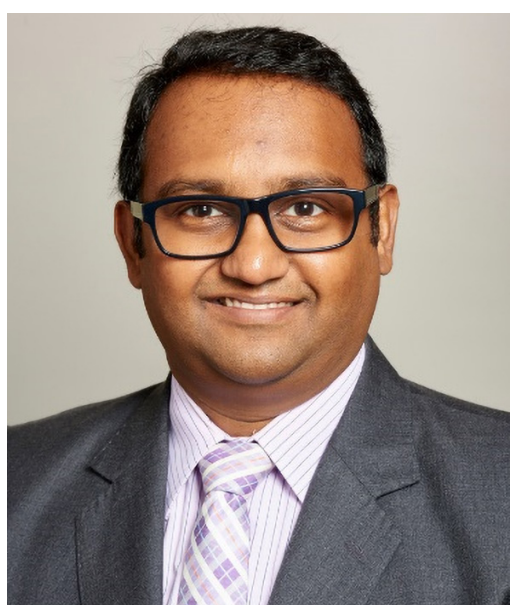

Raghav A. Murthy

Raghav A. Murthy, MD, DABS, FACS Division of Pediatric Cardiac Surgery, Department of Cardiovascular Surgery, Mount Sinai Hospital, New York, USA. (Email: raghavamurthy@yahoo.com) Submitted Nov 01, 2019. Accepted for publication Nov 25, 2019. doi: $10.21037 /$ jtd.2019.11.16

View this article at: http://dx.doi.org/10.21037/jtd.2019.11.16

Cite this article as: Murthy RA. Management of congenital heart disease. J Thorac Dis 2020;12(3):1159-1160. doi: $10.21037 /$ jtd. 2019.11 .16 